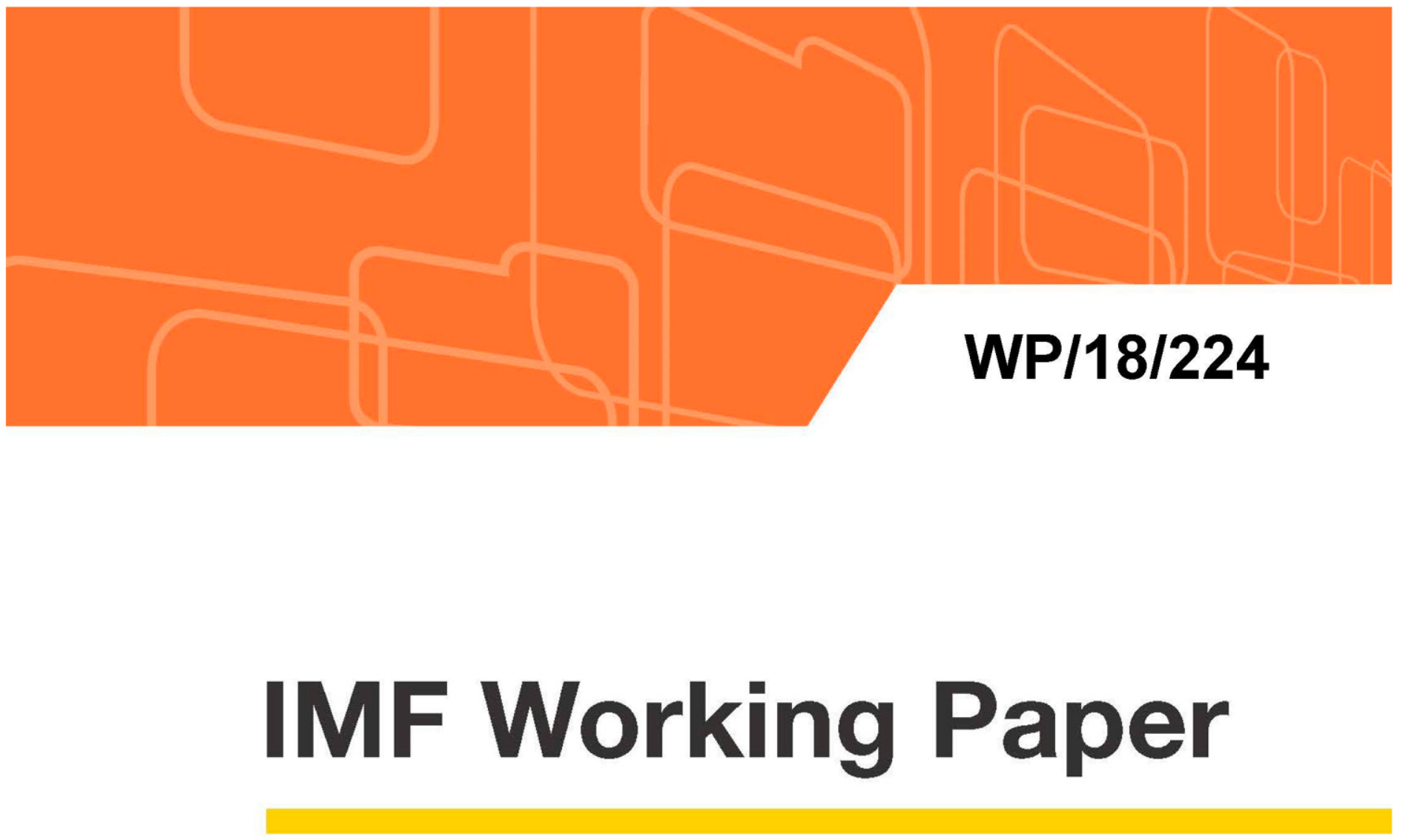

\title{
Structural Reform Priorities for Brazil
}

by Nina Biljanovska, Damiano Sandri

IMF Working Papers describe research in progress by the author(s) and are published to elicit comments and to encourage debate. The views expressed in IMF Working Papers are those of the author(s) and do not necessarily represent the views of the IMF, its Executive Board, or IMF management. 


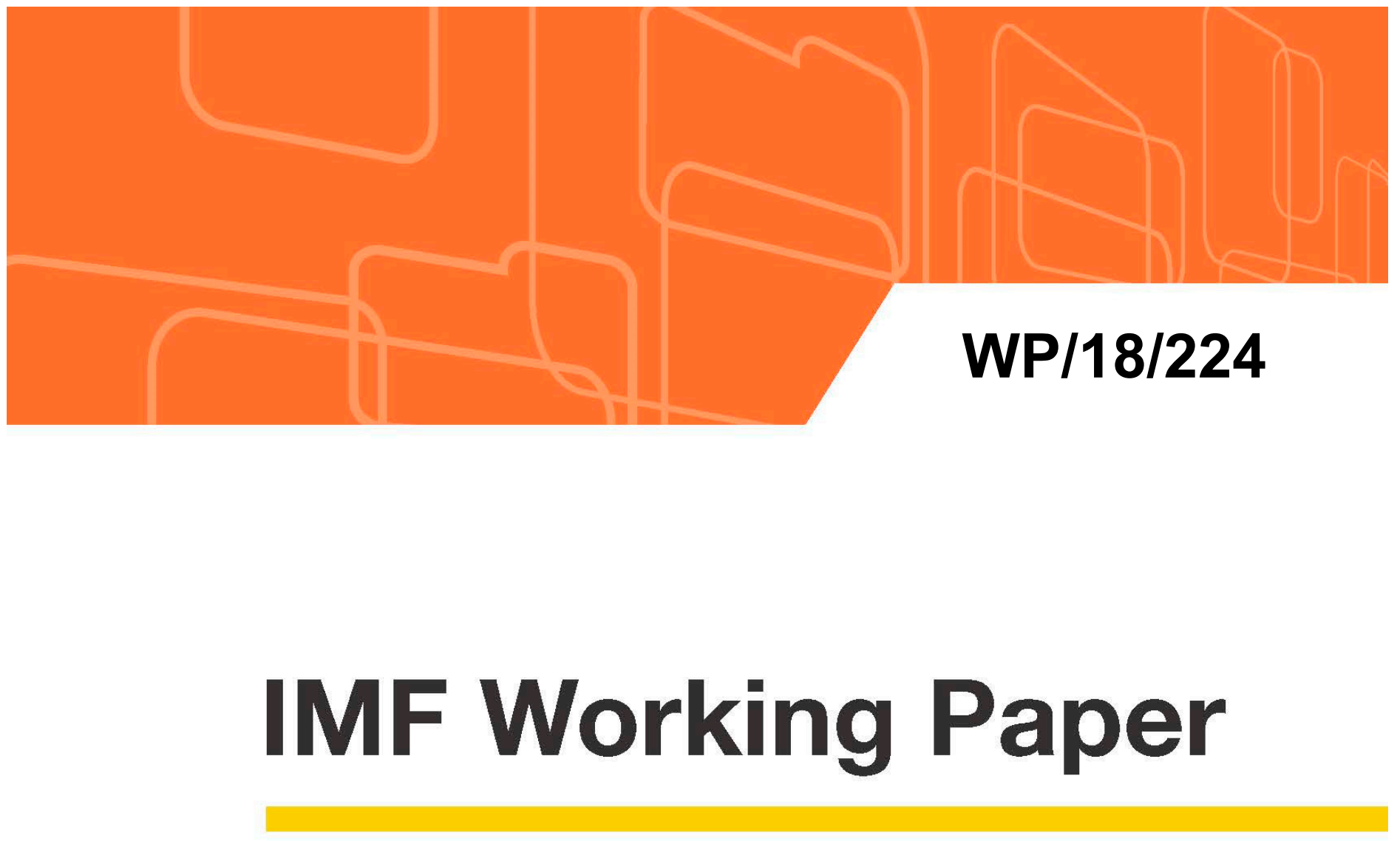

\title{
Structural Reform Priorities for Brazil
}

\author{
by Nina Biljanovska, Damiano Sandri
}

IMF Working Papers describe research in progress by the author(s) and are published to elicit comments and to encourage debate. The views expressed in IMF Working Papers are those of the author(s) and do not necessarily represent the views of the IMF, its Executive Board, or IMF management.

$$
\text { I N T E R N A T I O N A L M O N E T A R Y F U N D }
$$




\title{
IMF Working Paper
}

Western Hemisphere Department

\section{Structural Reform Priorities for Brazil}

\section{Prepared by Nina Biljanovska and Damiano Sandri}

Authorized for distribution by Antonio Spilimbergo

October 2018

\section{IMF Working Papers describe research in progress by the author(s) and are published to elicit comments and to encourage debate. The views expressed in IMF Working Papers are those of the author(s) and do not necessarily represent the views of the IMF, its Executive Board, or IMF management.}

\begin{abstract}
Over the last few decades, Brazil has experienced relatively weak economic growth due to stagnant productivity. To boost productivity, Brazil should embark on an ambitious structural reform process. In doing so, it is crucial that authorities select a few reform priorities to avoid dispersing political capital on an overly broad reform agenda. The paper aims to identify Brazil's reform priorities in two steps. First, it estimates the impact that different reforms have on Brazil's productivity. Second, it analyzes survey data to assess the extent of public support for reforms. The results show that banking sector reforms would generate the largest productivity gains and have the highest level of public support. Moreover, they would also be relatively easy to legislate and generate significant fiscal savings.
\end{abstract}

JEL Classification Numbers: E02, E60, C83

Keywords: Structural reforms, Brazil, political economy.

Author's E-Mail Address: nbiljanovska@imf.org, dsandri@imf.org 
ABSTRACT

I. INTRODUCTION $\underline{3}$

II. PRODUCTIVITY GAINS FROM STRUCTURAL REFORMS 4

III. PUBLIC SUPPORT FOR STRUCTURAL REFORMS $\underline{8}$

IV. BRAZIL'S REFORM PRIORITIES $\underline{16}$

V. ADDITIONAL CONSIDERATIONS TO IDENTIFY REFORM PRIORITIES $\underline{18}$

VI. CONCLUSIONS $\underline{19}$

REFERENCES $\underline{20}$ 


\section{INTRODUCTION}

Over the last few decades, Brazil has experienced relatively weak economic growth (Figure 1). From 1980 onwards, real GDP has grown at only about 2.6 percent per year, well below other major emerging market economies. Brazil's weak growth performance is largely due to stagnant total factor productivity (TFP), which has been roughly constant for about 40 years. In fact, if we exclude human capital accumulation using the estimates provided by the Penn World Tables up to 2014, TFP is today considerably lower than in the early 1980s.

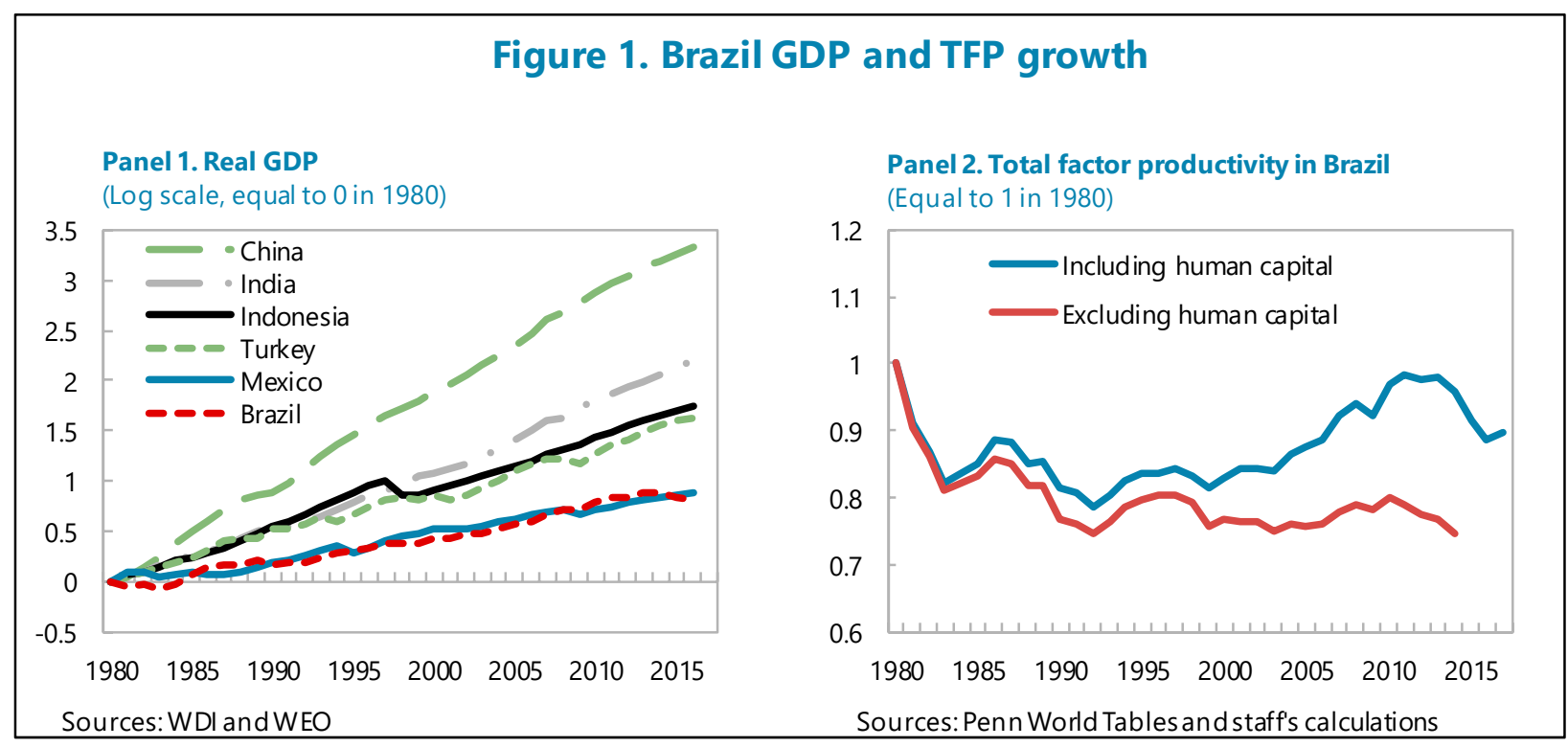

To raise productivity and potential growth, Brazil should adopt ambitious structural reforms. A large and growing empirical literature finds that structural reforms have positive effects on GDP growth, especially by boosting productivity. Most of the literature has focused on advanced economies for which structural reform indicators are more broadly available (Bouis and Duval, 2011; IMF, 2016). However, recent papers have documented that structural reforms can raise productivity also in emerging markets and low-income countries (Ostry et al., 2009; Prati et al., 2013). These papers have focused on the economic aspects of reforms, neglecting the political economy of consensus. This paper fills this gap.

A successful reform process requires setting clear policy priorities. Undertaking structural reforms is often an arduous political task. Despite generating benefits for society at large, reforms raise fierce opposition from those individuals that gain from existing market distortions and barriers to competition. Rather than dispersing political capital over an overly broad reform agenda, it is thus preferable to concentrate the reform efforts in a few critical areas.

This paper provides guidance on how to identify the main structural reform priorities for Brazil. It does so in two steps. First, in Section B we estimate the impact that several different structural reforms are likely to have on Brazil's productivity. Second, in Section C we use 
survey data to assess the extent of public support for specific reforms. By drawing on the insights of these two sections, section D identifies those reforms that are likely to have the highest growth payout at the lowest political cost. We also differentiate reforms depending on their legislative requirements and fiscal impact. Section E presents some additional considerations that can influence the choice of reform priorities and Section D concludes by summarizing the key insights of the analysis

\section{Productivity Gains From STRUCTURAL REFORMS}

\section{This section identifies which structural reforms in Brazil are likely to boost productivity}

the most. To do so, we first estimate the impact that several different structural reforms have on productivity based on a sample of both advanced and emerging market countries. Second, we use these estimates to assess the impact on productivity if Brazil undertakes reforms that bring its structural indicators up to the average levels in advanced economies.

We consider a broad range of structural reform indicators. Measuring the degree of structural reforms is notoriously difficult. In most instances, structural reforms are associated with policy measures that support free-market outcomes, for example by removing barriers to entry and reducing state intervention. However, structural reforms can also include measures to address market failures, for example by improving banking regulation and supervision. In this paper, we consider several indexes of structural reforms taken from Prati et al. (2013) and IMF (2015):

- Banking sector: this index is based on the methodology in Abiad and Mody (2005) and Abiad et al. (2010), which captures the presence of interest rate controls, directed credit, public banks, restrictions to bank competition, and the quality of banking supervision and regulation.

- Labor market: labor reforms are measured as the average of two indexes from the Global Competitiveness Report, capturing the ease with which employers can hire and fire workers and the extent to which wages can be freely determined at the firm level rather than being set through collective bargaining.

- Legal system: this index, assembled by the EFW-Fraser Institute, gauges the legal protections afforded to persons and their property, considering the rule of law, property rights, the independence of the judiciary, and the impartial and effective enforcement of the law.

- Product market: this index, constructed by the Economist Intelligent Unit, measures the extent to which government policies curb monopoly power and promote competition.

- Trade Openness: rather than measuring trade openness using tariffs that in previous studies are found not related to productivity, we use an index introduced by Quinn (1997) which captures restrictions to payments associated with international trade of goods and services. 
All indexes are normalized between zero and one, with higher values corresponding to higher levels of structural reforms. Some of these indexes, especially for the labor market and legal system, are constructed using surveys of public perceptions and should thus be interpreted with caution.

A notable shortcoming of the analysis is the absence of established structural indicators for fiscal reforms. To make up for this, the IMF Staff Report (2015) presents several case studies which demonstrate the importance of structural fiscal reforms for macroeconomic performance. In Brazil, tax reforms to simplify the federal tax system, harmonize federal and state tax regimes, and remove distortionary tax exemptions can play an important role in raising productivity.

To estimate the impact of structural reforms on productivity, we follow the econometric approach in IMF (2015). The growth rate of TFP, $g$ TFP $P_{i, t}$, is regressed over the one-year lagged values of the structural reform indexes, $S R_{i, t-1}$, according to

$$
g T F P_{i, t}=\alpha+\beta \cdot \ln T P F_{i, t-1}+\gamma \cdot S R_{i, t-1}+\mu_{t}+v_{i}+\varepsilon_{i, t}
$$

The regression controls for the level of TFP and includes time and country fixed effects, respectively denoted with $\mu_{t}$ and $v_{i}$. The estimation is done on a sample of 86 advanced and emerging countries with data between 1970 and 2011 based on the dataset used in IMF (2015).

The regression results show that structural reforms have positive effects on productivity growth. Columns $1-5$ in Table 1 report the estimates of the regression coefficients $\gamma$ which capture the impact of a given structural reform indicator on the one-year-ahead growth rate of

\begin{tabular}{|c|c|c|c|c|c|c|c|}
\hline & (1) & (2) & (3) & (4) & (5) & (6) & (7) \\
\hline & \multicolumn{5}{|c|}{ TFP } & \multicolumn{2}{|c|}{ Investment } \\
\hline Banking sector & $\begin{array}{c}3.68^{\star \star \star} \\
(0.71)\end{array}$ & & & & & $\begin{array}{c}6.72^{\star \star \star} \\
(2.52)\end{array}$ & \\
\hline Labor market & & $\begin{array}{c}3.48^{\star \star \star} \\
(0.88)\end{array}$ & & & & & \\
\hline Legal system & & & $\begin{array}{c}2.33^{\star \star \star} \\
(0.77)\end{array}$ & & & & $\begin{array}{c}7.83^{\star \star \star} \\
(2.92)\end{array}$ \\
\hline Product market & & & & $\begin{array}{l}2.64^{\star \star} \\
(1.11)\end{array}$ & & & \\
\hline Trade openess & & & & & $\begin{array}{l}1.24^{\star} \\
(0.73)\end{array}$ & & \\
\hline Observations & 1,840 & 1,283 & 2,349 & 848 & 2,389 & 1,695 & 2,200 \\
\hline R-squared & 0.12 & 0.31 & 0.19 & 0.28 & 0.10 & 0.08 & 0.12 \\
\hline Number of countries & 62 & 83 & 71 & 53 & 77 & 60 & 70 \\
\hline
\end{tabular}


TFP. ${ }^{1}$ In line with the literature, the coefficients are positive and statistically significant. Columns 6-7 show that reforms of the banking sector and legal system have also a positive impact on real investment growth. ${ }^{2}$ Therefore, besides raising productivity, they also stimulate capital accumulation.

To assess the impact of structural reforms on Brazil's productivity, we interact the regression coefficients with Brazil's structural gaps. We measure Brazil's structural gaps relative to the average levels prevailing in advanced economies. ${ }^{3}$ Figure 2 shows that Brazil lags advanced economies significantly across all structural reform indicators. By multiplying Brazil's structural gaps with the regression coefficients in Table 1, we can estimate by how much TFP growth would increase if Brazil undertakes reforms that raise its structural indicators to the average levels in advanced economies.

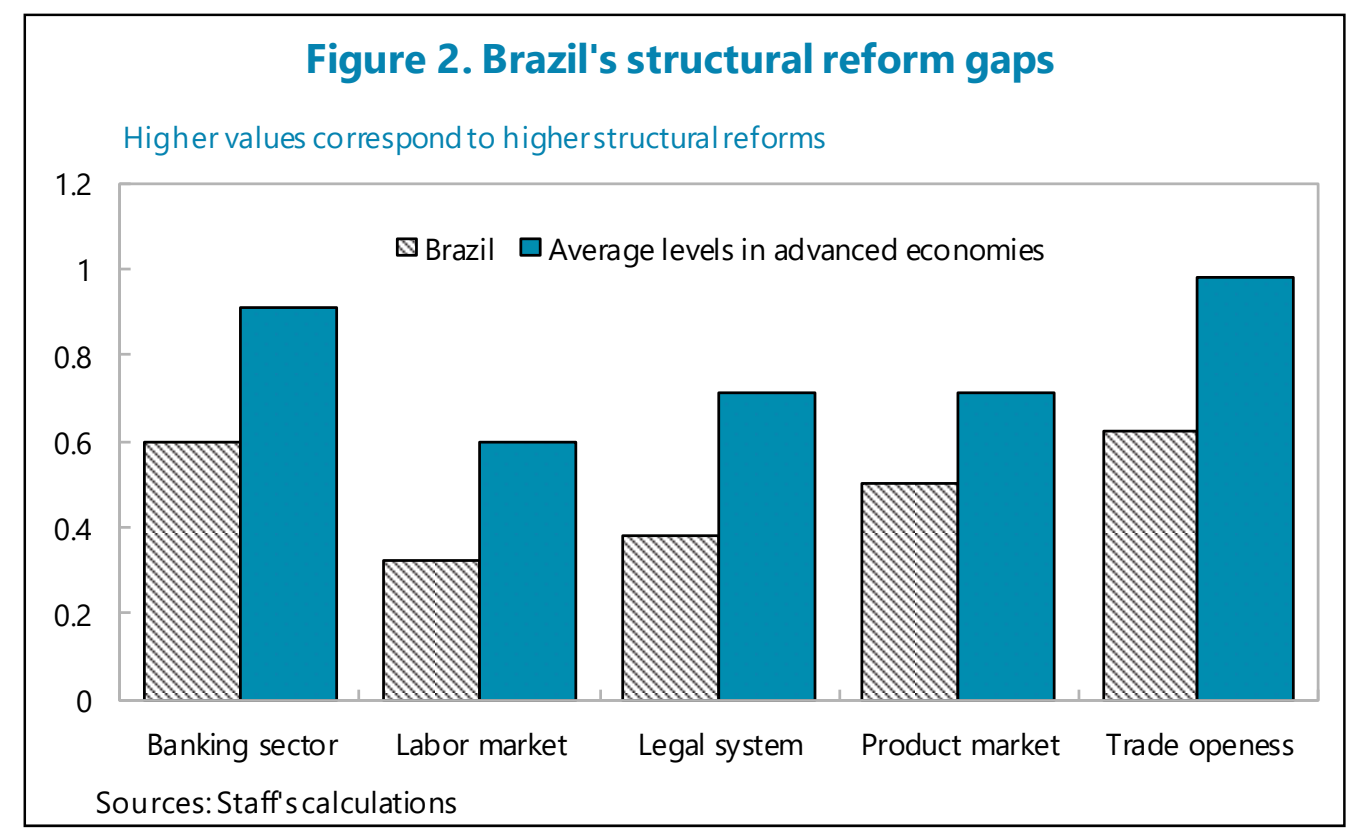

The results show that banking sector reforms are likely to have the strongest impact on productivity. Figure 3 shows the impact on productivity growth from undertaking structural reforms that bring Brazil up to the average level in advanced economies. Structural reforms of the banking sector are predicted to have the largest effects on productivity, raising the one-yearahead TFP growth by almost 1.2 percent.

\footnotetext{
${ }^{1}$ The analysis could be replicated by looking at the medium and long-term impacts of reforms. We prefer to focus on the short-term effects in line with our emphasis on identifying reforms that can be politically more palatable by delivering quick results.

${ }^{2}$ Banking and legal reforms are also the ones that remain statistically significant if all structural indicators are included at the same time.

${ }^{3}$ To calculate structural gaps, we update the structural reform indicators for Brazil to the most recent available year.
} 


\section{Bank reforms should aim to reduce state-intervention in credit markets and promote} privatization. The structural reform indicator for the banking sector is an average of several subcomponents following the methodology presented in Abiad and Mody (2005) and Abiad et al. (2010). By looking at the subcomponents, we can identify specific areas where structural reforms are needed the most. Brazil fares relatively well with regard to bank supervision, low levels of entry barriers, and free setting of interest rates by private banks. However, Brazil scores quite poorly because of pervasive state-intervention in credit allocation and the presence of large public banks.

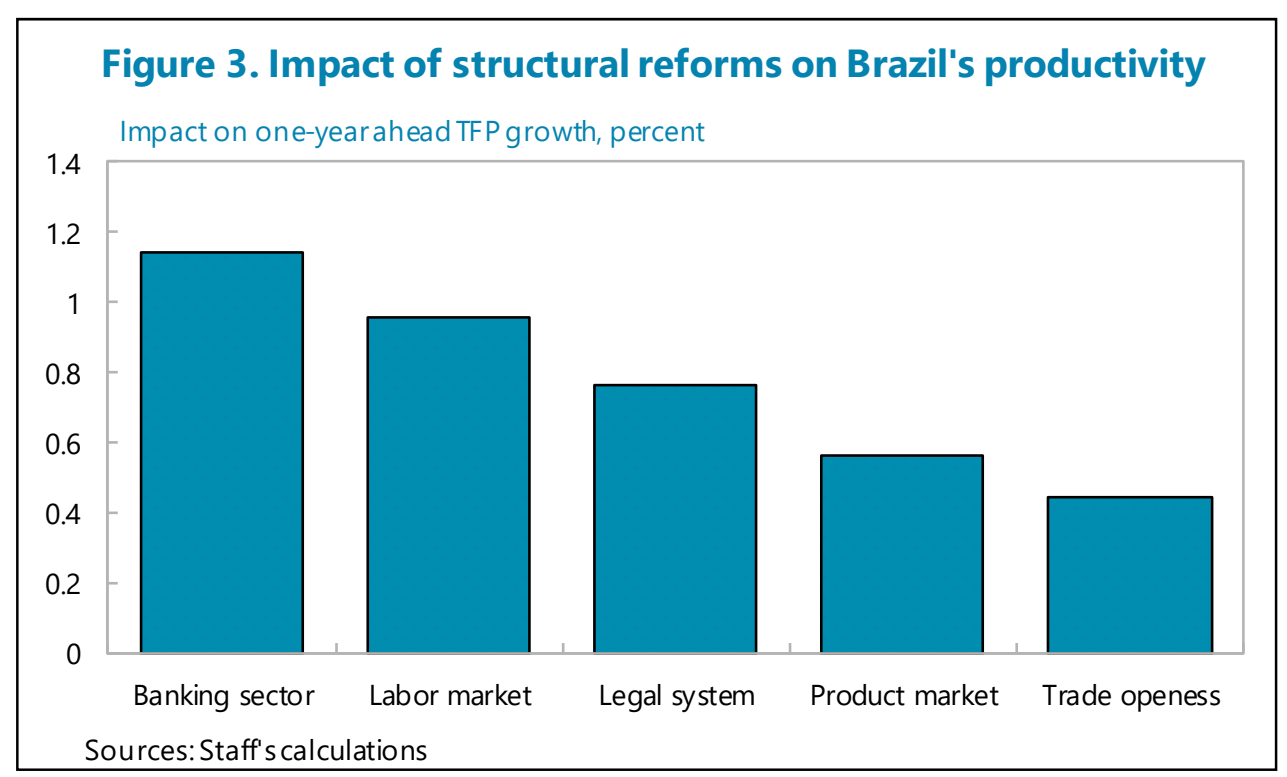

Labor market reforms have also a significant impact on productivity, but the analysis may overestimate the scope for further reforms. The structural indicators of the labor market are based on employers' perceptions about rigidities in hiring/firing and wage setting surveyed before September 2017. Therefore, they don't yet reflect the improvements associated with the labor reform that came into effect in November 2017. The scope for further labor reforms might thus be more limited than suggested by the analysis.

Besides banking reforms, Brazil would benefit greatly from measures to improve the legal system. Figure 3 shows that legal reforms would boost productivity significantly. For example, authorities should consider measures to increase the efficiency of the court system, such as by preventing the abuse of appeals provisions and statutes of limitations in legal proceedings. These reforms would also assist in reducing corruption that is likely to also raise productivity. The structural indicator for legal reforms used in the analysis is indeed strongly correlated with corruption indexes provided by the World Governance Indicators and International Crisis Risk Guide. This suggests that the productivity gains associated with improvements in the legal system are likely to also capture the benefits from curbing corruption. 
The effects of product market and trade reforms appear more limited, but still sizeable. Measures to enhance competition and further open the economy to international markets would have a positive impact on productivity in Brazil. Nonetheless, the effects are more limited, equal to about half of the gains that can be seized with banking sector reforms. Trade and product market reforms fare relatively better when considering the impact on long-term GDP growth as documented in OECD (2018).

\section{PUbliC SUPPORT FOR STRUCTURAL REFORMS}

This section uses survey data to identify which structural reforms have the highest support among the public in Brazil. We draw data from the Latin Barometer Survey and the Pew Global Attitudes and Trends Survey, both of which collect information over time and across countries on people's views regarding various economic, political, and social issues. We focus on questions covering economic issues, from which we can infer public attitudes toward specific structural reforms.

We begin the analysis by considering the extent of public support for a free-market economy. We assess public opinion over time and across 18 Latin American countries by looking at the following Latin Barometer question:

Q: The market economy is the only system with which the country can become developed. ${ }^{4}$

Over the period 2003-16, 63 percent of the Brazilian public on average agreed (or strongly agreed) with the statement above, suggesting that the majority believe that a free-market system is essential for development. When compared to the rest of Latin America (LATAM), the support for free markets in Brazil is among the highest in the region (Figure 4, Panel 1). ${ }^{6}$

\footnotetext{
${ }^{4}$ The respondents are given to choose among five possible answers: (i) strongly agree, (ii) agree, (iii) disagree, (iv) strongly disagree, and (v) don't know. We construct the support for market economy variable by adding the share of people who "strongly agree" and "agree" with the statement.

${ }^{5}$ Participants are asked this question in every survey in the period 2003-16.

${ }^{6}$ Rest of LATAM countries: Argentina, Bolivia, Chile, Colombia, Costa Rica, Dominican Republic, Ecuador, El Salvador, Guatemala, Honduras, Mexico, Nicaragua, Panama, Paraguay, Peru, Uruguay and Venezuela.
} 


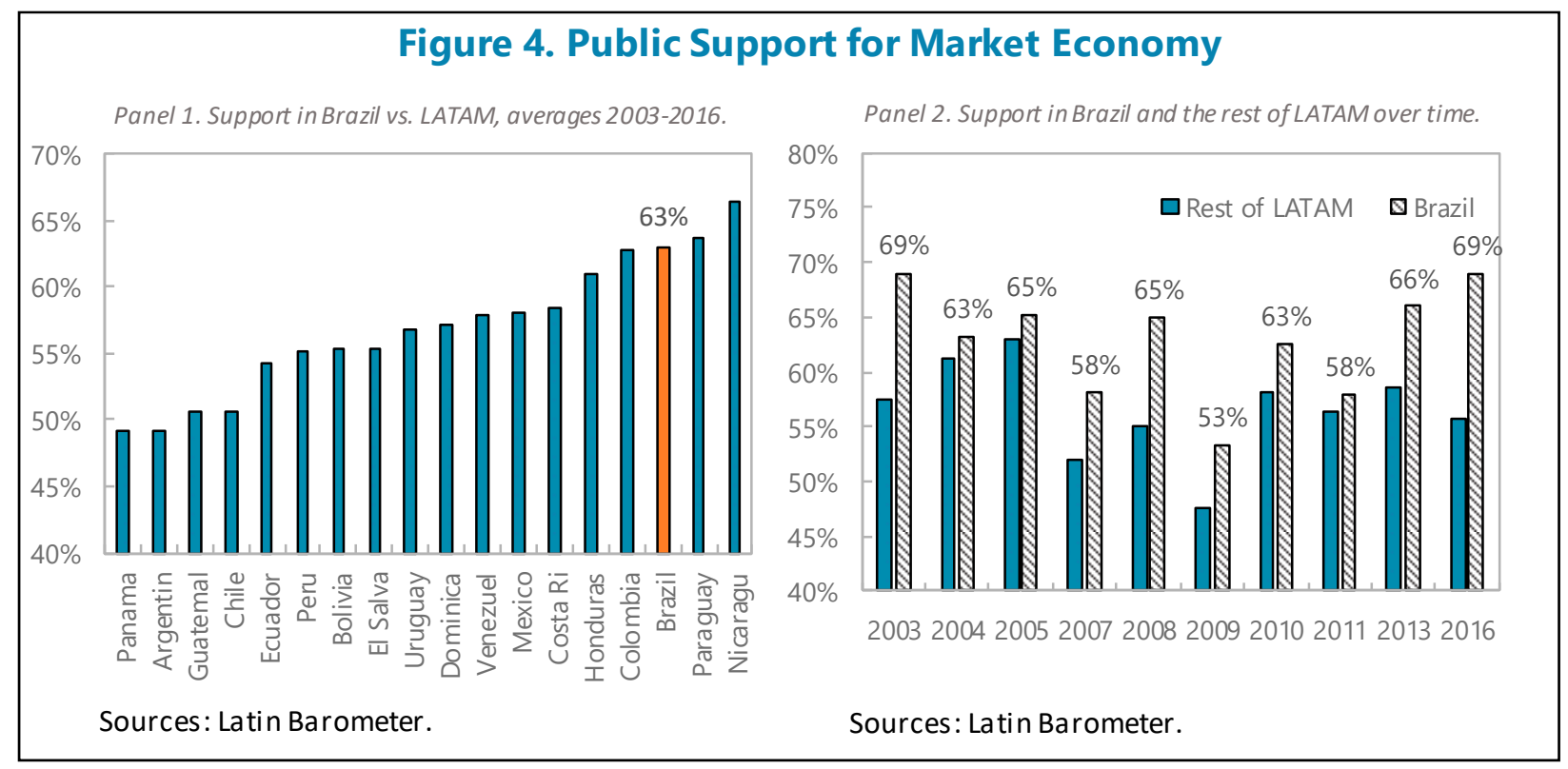

Public support for a market-based system has been high in Brazil over time and consistently above the LATAM average (Figure 4, Panel 2). Nonetheless, public support for free markets dropped sharply in 2009 from 65 to 53 percent. This decline likely reflected concerns with the process of financial deregulation in advanced economies that led to the Global Financial Crisis. On the contrary, support for free markets reached the highest level in 2016, at almost 70 percent, in conjunction with Brazil's recent recession. Given that Brazil's 2015-16 recession was highly idiosyncratic, the higher support for free-markets could be explained by the desire to correct the structural imbalances present in the domestic economy.

Growth increases support for free markets. We now examine more systematically the comovement between the public support for free markets and real output growth, controlling for other macro variables. In a panel of 18 Latin American countries and over the period $2003-2016,{ }^{7}$ we estimate the following regression equation:

$$
\operatorname{Mrkt}_{i, t}=\alpha+\beta \cdot g d p_{i, t}+\boldsymbol{\gamma}^{\prime} \cdot \boldsymbol{X}_{i, t}+{ }_{v_{i}}+\varepsilon_{i, t} .
$$

The variable $M r k t_{i, t}$ denotes the percentage of people in country $i$ and year $t$ agreeing (or strongly agreeing) with the statement that the market economy is the only system with which the country could become developed; $g d p_{i, t}$ denotes the real growth rate of GDP; $\boldsymbol{X}_{i, t}$ is a vector of macroeconomic variables, including the fiscal impulse, inflation, and the unemployment rate. The regression results are shown in Table 2. Across all specifications, real GDP growth is positively associated with higher public support for free-market reforms. Accommodative fiscal policy may be marginally promoting support, whereas inflation and unemployment do not play an important role.

\footnotetext{
${ }^{7}$ See footnote 7 for the list of countries included in the regression analysis in addition to Brazil.
} 


\begin{tabular}{|c|c|c|c|c|c|}
\hline & $(1)$ & $(2)$ & (3) & (4) & (5) \\
\hline & OLS & OLS & OLS & OLS & IV \\
\hline \multirow[t]{2}{*}{ GDP growth } & $0.64^{\star \star \star *}$ & $0.83^{\star \star \star}$ & $0.89^{\star \star \star}$ & $0.89^{\star \star \star}$ & $1.74^{\star \star \star}$ \\
\hline & $(0.19)$ & $(0.25)$ & $(0.26)$ & $(0.26)$ & $(0.42)$ \\
\hline \multirow[t]{2}{*}{ Fiscal impulse } & & $0.76^{\star}$ & 0.70 & 0.69 & 0.54 \\
\hline & & $(0.42)$ & $(0.42)$ & $(0.43)$ & $(0.46)$ \\
\hline \multirow[t]{2}{*}{ Inflation } & & & 0.18 & 0.18 & 0.22 \\
\hline & & & $(0.15)$ & $(0.15)$ & $(0.16)$ \\
\hline \multirow[t]{2}{*}{ Unemployment } & & & & 0.01 & 0.12 \\
\hline & & & & $(0.39)$ & $(0.41)$ \\
\hline Observations & 178 & 105 & 104 & 104 & 104 \\
\hline R-squared & 0.07 & 0.14 & 0.16 & 0.16 & \\
\hline Number of country & 18 & 11 & 11 & 11 & 11 \\
\hline
\end{tabular}

The positive effect of growth on free-market support is robust to using instrumental variables. One concern that arises with our baseline specification is the risk of omitted variable bias. There may indeed be other factors driving both growth and support for free markets which we are not controlling for, resulting in biased estimates. To address this problem, we estimate an instrumental variable regression, using real global growth as an instrument for real domestic growth. The coefficient on domestic real growth remains highly statistically significant and becomes somewhat larger. The results are also robust to estimating the baseline regression equation with the dependent variable specified in first differences rather than levels.

Which structural reforms does the public support the most? To identify the specific structural reforms supported by the public, we analyze the following question from the Latin Barometer Survey: ${ }^{8}$

\section{Q: "What is most important for the development of Brazil?"}

The range of choices include: (i) Social policy, (ii) Gender equality, (iii) Infrastructure, (iv) Environment, (v) Innovation, (vi) Productivity, (vii) Quality of public institutions, (viii) Integration to the world, (ix) Rule of law, (x) Equity of opportunity, and (xi) Human capital. ${ }^{9}$ While this question does not ask respondents directly about structural reforms, it communicates views on what aspects of the economy need to be strengthened for the country's

\footnotetext{
${ }^{8}$ We would ideally use a survey dataset that asks participants questions about their views on specific structural reforms (e.g. Baker, 2000). However, these types of questions are generally not covered by population representative surveys such as the Latin Barometer, Pew Global Attitudes Project, Latin American Public Opinion Project and Datafolha (Brazil).

${ }^{9}$ Respondents can select multiple choices.
} 
development. Based on the respondents' answers (Figure 5), we build our measure of public support for structural reforms.

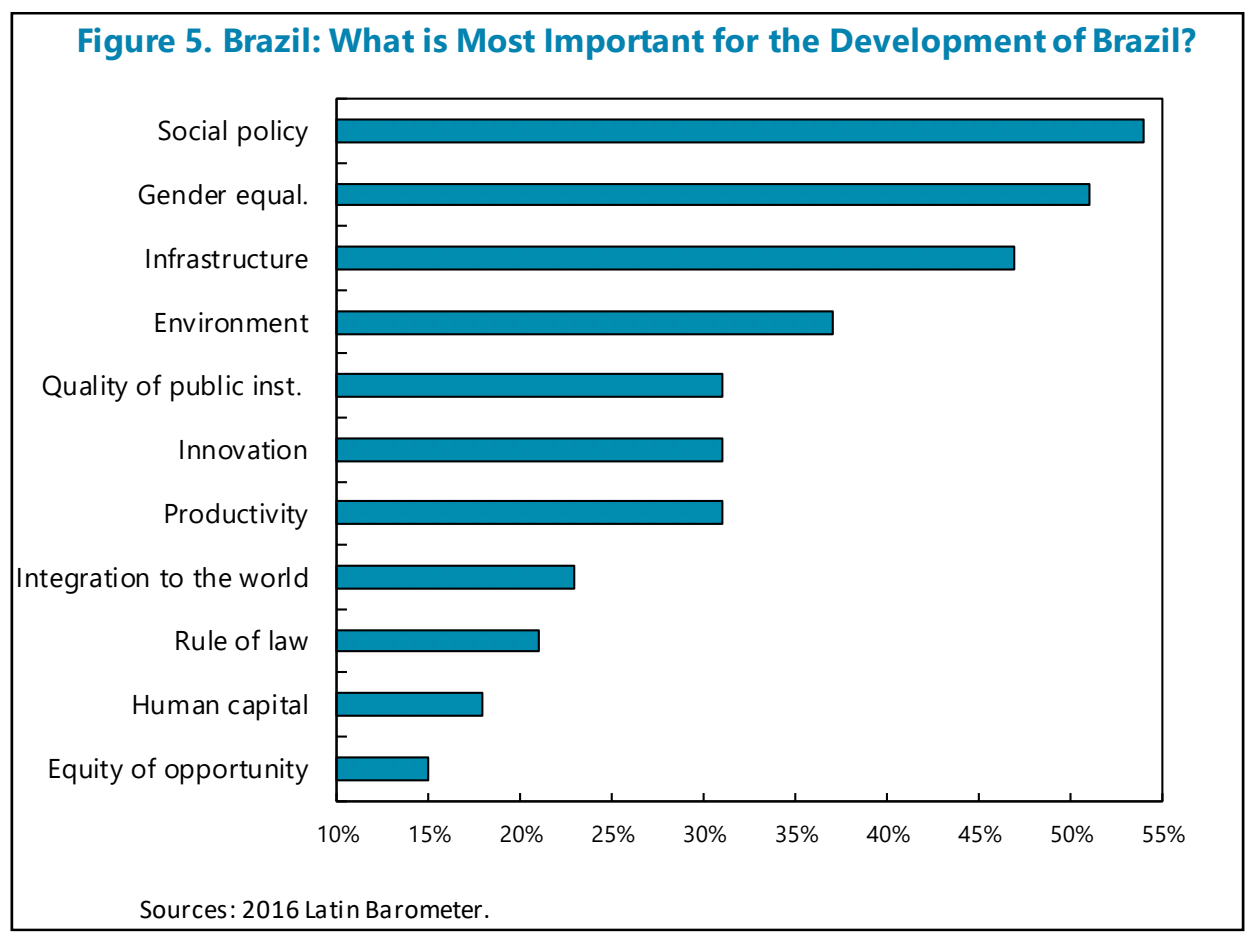

As illustrated in Table 3, matching survey responses to structural reforms involves some judgment. For some reforms, the matching with survey responses is rather straightforward. For example, we interpret respondents' choice for "Integration to the World" to be indicative of public's support for free-trade reforms. Similarly, we interpret respondents' choice of "Rule of Law" and "Quality of Public Institutions" as signaling public support for legal system reforms. The matching procedure is more challanging when it comes to product market/banking sector and labor market reforms. Under the assumption that product and banking reforms can bolster productivity and innovation, we tie these two reforms to support for "Innovation" and "Productivity." Finally, we interpret people's demand for "Equity of opportunity" as a measure of public support for a more equitable and meritocratic labor market. ${ }^{10}$ To validate our matching procedure for banking sector, product market, and labor market reforms we consider in the next paragraph their correlation with structural reform indicators.

\footnotetext{
${ }^{10}$ The rest of the answers from the question do not correspond to structural reforms and therefore were omitted.
} 
Table 3. Matching survey responses to structural reforms

\begin{tabular}{ll}
\hline Survey response(s) & Structural reform \\
\hline Integration to the World & Trade openness \\
\hline Rule of Law & Legal system \\
Quality of Public Institutions & Banking / Product market \\
\hline $\begin{array}{l}\text { Productivity } \\
\text { Innovation }\end{array}$ & Labor market \\
\hline Equity of Opportunity &
\end{tabular}

Measures of public support for specific reforms are correlated with structural reform indicators, supporting our matching procedure. Figure 6 shows the relationship between people's support for "Innovation" and "Productivity" and the level of product and banking reforms measured with the indexes described in section B. In countries where product and banking reforms are weak, respondents consider "Innovation" and "Productivity" as more beneficial for development. Similarly, respondents report "Equity of opportunity" as an important factor for development, especially in countries with rigid labor markets. These results give us some comfort for our matching algorithm that uses "Innovation" and "Productivity" and "Equity of opportunity" as proxies for public support for product market/banking sector and labor market reforms, respectively.

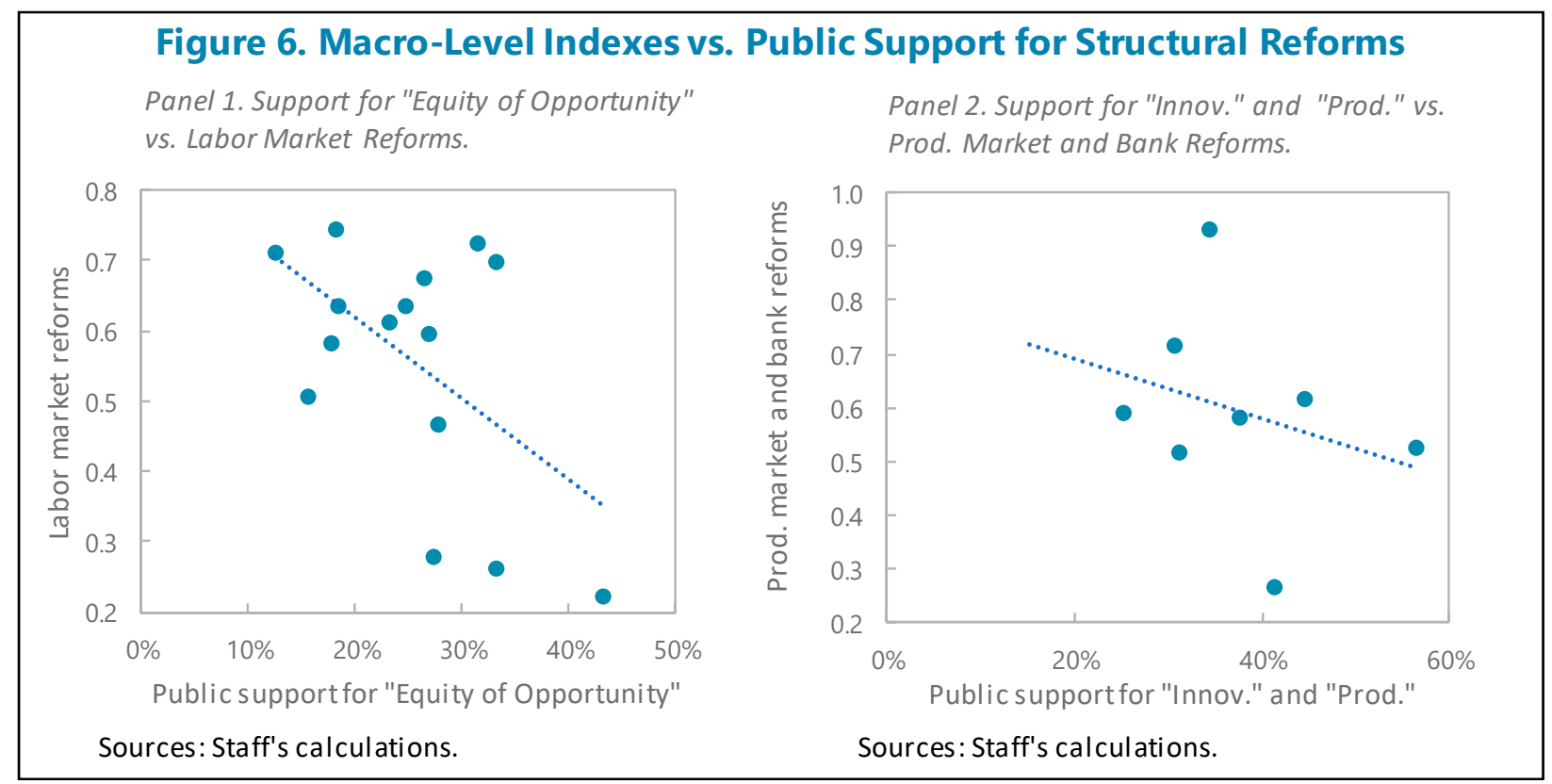

Product, banking and legal system reforms receive the highest level of public support in Brazil. Based on our analysis, about 30 percent of the sample surveyed in Brazil supports 
product market and banking sector reforms (Figure 7). Similarly, about a quarter of the respondents believe that legal system reforms are important for development. Trade reforms are supported by 23 percent of respondents. Finally, only 15 percent believe that improving labor laws could contribute to development.

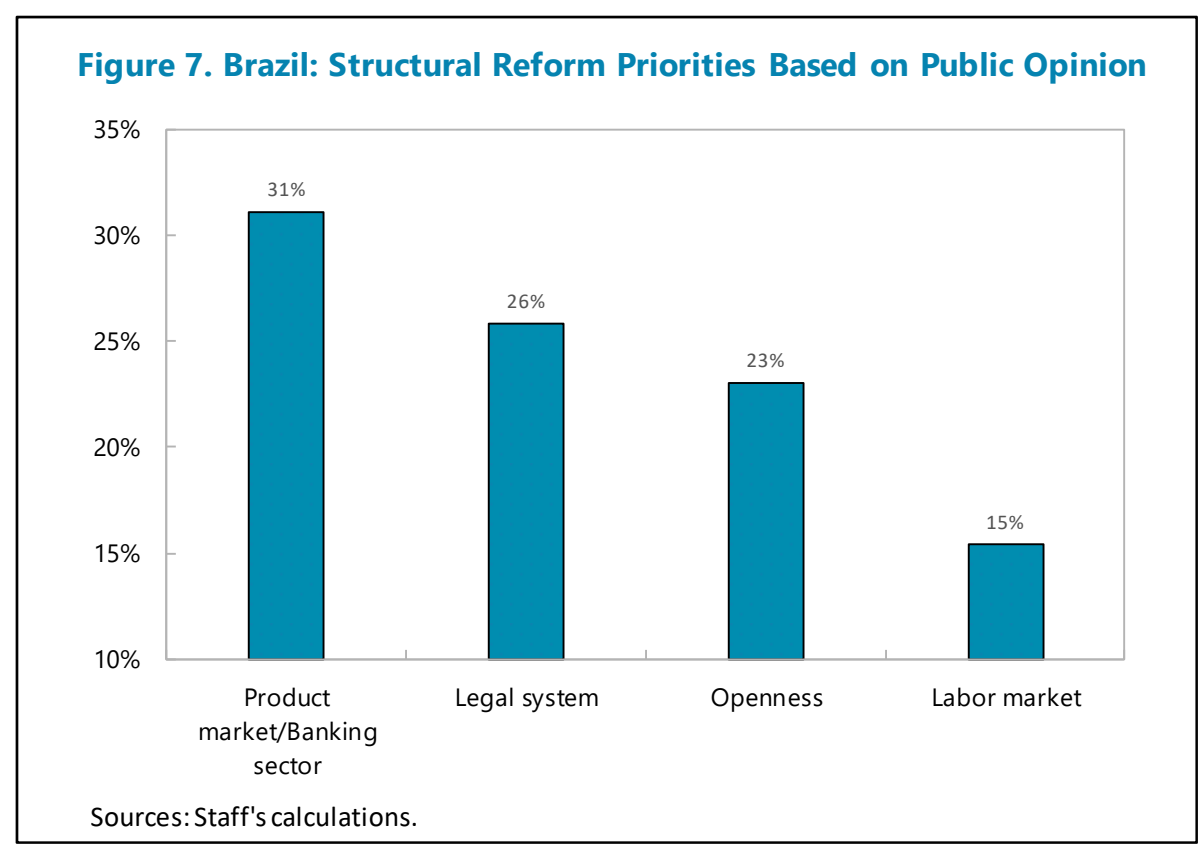

\section{Discontent with the banking sector and legal system is also evident in the Pew Global}

Attitudes Survey. To corroborate our findings and ensure they are not specific to the Latin Barometer, we look at the following two questions from the Pew Global Attitudes Survey:

- Q: "Is the influence of banks and other financial institutions good?"

- Q: "Is the influence of the Court System good?"

More than half of the respondents in the sample consider the influence of financial institutions to be "somewhat bad" or "very bad" (Figure 8). In addition, more than 70 percent of the respondents consider the court system to have a poor influence, suggesting that there is scope for improvement through structural reforms. 
Figure 8. Brazil: Public View of Financial Legal Institutions

Panel 1. Is the influence of banks and other financial institutions good?

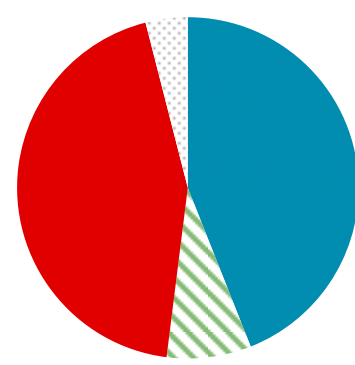

- Somewhat bad

Very bad

- Somewhat good

Very good

Sources: Pew Global Attititudes \& Trends Survey.
Panel 2. Is the influence of the court system good?

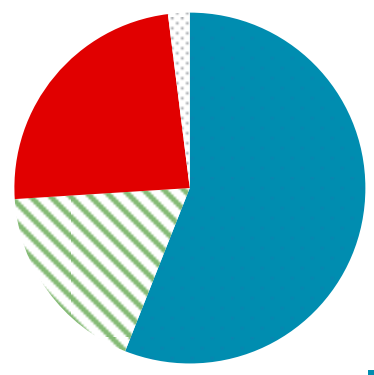

- Somewhat bad

Very bad

- Somewhat good

Very good

Sources: Pew Global Attititudes \& Trends Survey.

Using micro level data from Latin Barometer, we further analyze which segments of the society are more likely to support reforms. The priority list of reforms may vary across different groups in the society since the costs and benefits associated with reforms may differ across different demographic and socioeconomic characteristics. To account for this, we estimate the following regression equation based on 2016 Latin Barometer Survey data for Brazil

Support_Reform ${ }_{i}^{S}=\alpha+\beta \cdot E D U_{i}+\gamma_{1} \cdot A G E_{i}+\gamma_{2} \cdot A G E_{i}^{2}+\delta \cdot \mathrm{EMPL}_{i}+\varphi \cdot \mathrm{GENDER}_{i}+\varepsilon_{i}$.

Here Support_Reform ${ }_{i}^{s}$ is a dummy variable denoting individual's $i$ support for reform $s$, where $s$ stands for product market and banking sector, legal system, labor market or trade reforms; the explanatory variables include the individual's years of education, age, age squared (to account for non-linearities), employment status, and gender, respectively.

The level of education is a strong predictor of support for reforms. The regression coefficients associated with years of education are positive and statistically significant across all reform categories in Table 4. Not much variation is instead detected across other demographic and socioeconomic characteristics, thus suggesting that support for reforms is rather homogenous across the population. The employment status matters only for labor market reforms, with the unemployed or self-employed being more supportive of labor reforms. Age appears instead to affect people's views about trade, with older people being less supportive of reforms. 


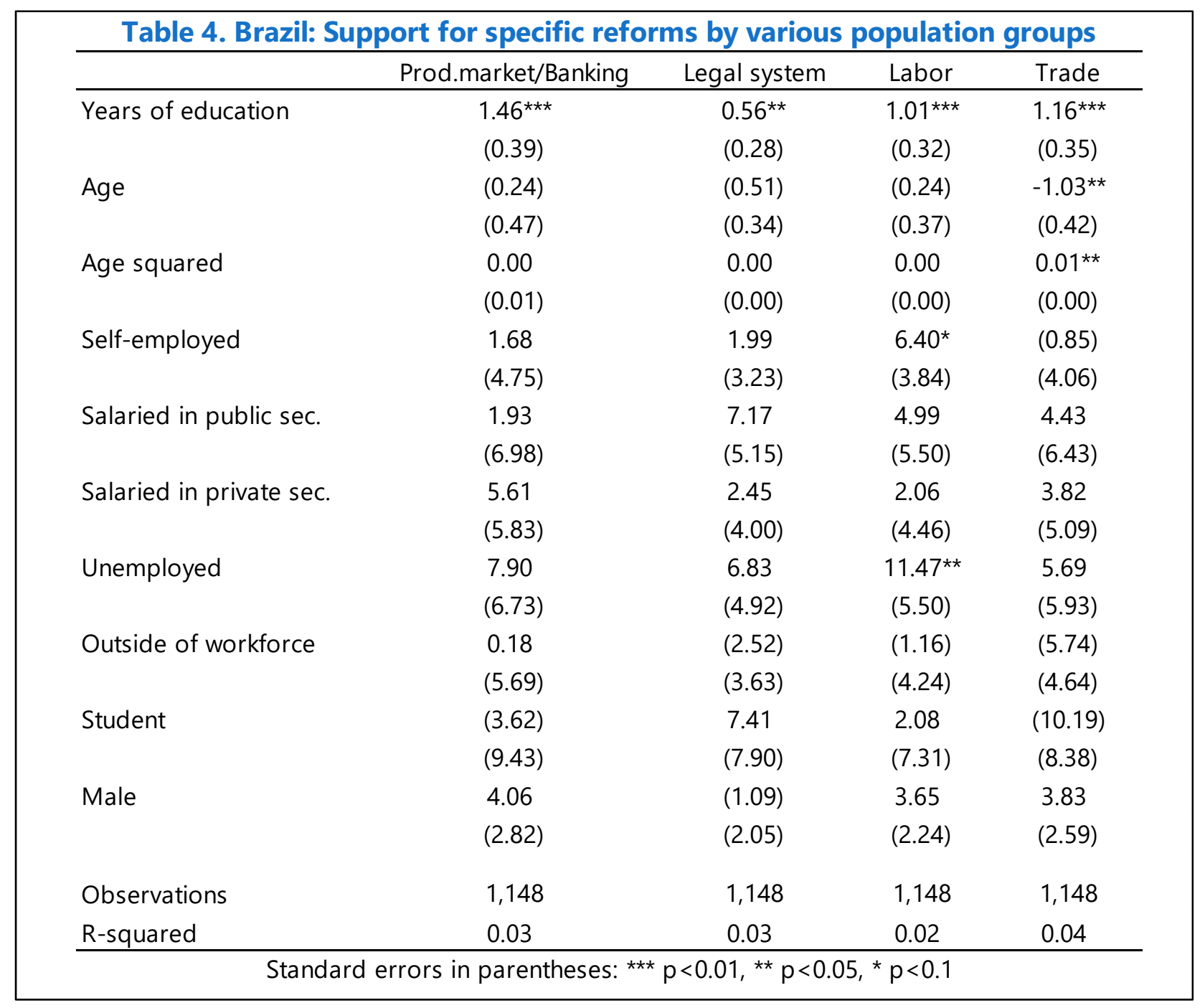

The survey regressions further corroborate our procedure to assess public support for labor market reforms. The result that unemployed and self-employed individuals are on average more supportive of labor market reforms than the rest of the population suggests that the survey answer "Equity of opportunity" is a good proxy for public support for labor market reforms. Hence, our approach is also validated by micro level data.

\section{Despite broad public support, the reform agenda may be undermined by special interests.}

One caveat to the analysis is that public support does not necessarilly translate into political action since special interest groups can have a powerful impact on the legislative process. The political science literature has not yet taken a definite stand on the extent to which public opinion influences policy makers decisions. ${ }^{11}$ Studies suggest that the balance of power between public support and special-interest groups depends on the prominence of the subject, the degree

\footnotetext{
${ }^{11}$ On one hand, Monroe (1979), Page and Shapiro (1992), and Stimson (2004) argue that policy-makers follow public support; on the other, Zaller (1992) and Kingdon (2003) find that policy elites sway public opinion toward their viewpoint.
} 
of agreement among the public, the intensity with which opinions are held, and the extent of organized support for and against the opposition. Nonetheless, even though the opinion of the public may not necessarilly be the only driver for political action, it certainly plays a significant role.

\section{BRAZIL'S REFORM PRIORITIES}

In this section, we combine our findings about the effects on TFP and the extent of public support to identify Brazil's structural reform priorities. Figure 9 presents a scatter plot of the structural reforms considered in the analysis, showing on the horizontal axis the estimated effects on TFP growth and on the vertical axis the degree of public support. Structural reforms closer to the top-right corner are thus the ones likely to boost productivity the most, while gathering the largest support among Brazil's population.

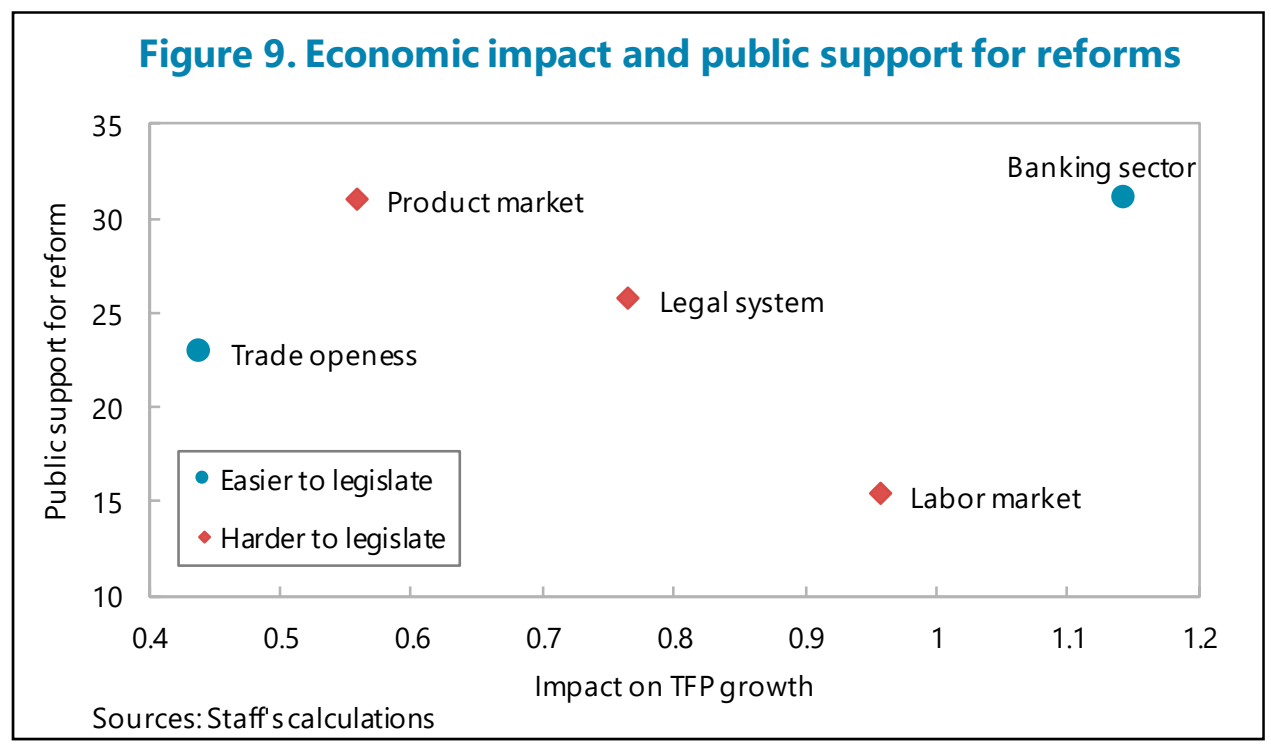

Banking sector reforms have the strongest impact on TFP and the highest level of public support. They should thus feature at the top of the structural reform agenda for Brazil. As previously discussed, the structural indicator for the banking sector suggests that policy efforts should focus on improving credit allocation by limiting state intervention. Legal reforms should also be given high priority, especially if they contribute to reducing corruption. They are indeed supported by a large proportion of the population and have strong positive effects on productivity.

Besides the effects on TFP and the extent of public support, legislative considerations can also influence the choice of reforms. Table 5 lists several structural reforms that have been recently adopted or are under consideration in Brazil together with their legislative requirements. Some policy measures can be adopted relatively easily by the government without requiring approval by the Congress. These include recent initiatives to reform BNDES and Caixa and measures to foster trade integration. At the opposite spectrum, some measures require 
congressional approval through ordinary law, for example labor reforms. Finally, in some cases, the government can adopt measures on a temporary basis through provisional laws which need to be later confirmed by the Congress.

\begin{tabular}{|lll|}
\hline \multirow{3}{*}{ Structural reform category } & Table 5. Legislative requirements for structural reforms \\
\hline \multirow{3}{*}{ Banking sector } & Measures & Legislative requirements \\
& TLP reform to reduce subsidies on long-term rates (law 13483) & Provisional law \\
& Reform of BNDES's business model & Congress approval not required \\
& Reform of CAIXA's governance and business model & Congress approval not required \\
\hline \multirow{3}{*}{ Labor market } & Labor reform (law 13467) & Ordinary law \\
& Outsourcing of core business actvities (law 13429) & Ordinary law \\
& Migration reform (law 13455) & Ordinary law \\
\hline \multirow{3}{*}{ Legal system/corruption } & Ten measures against corruption (PLC 27/2017) & Ordinary law \\
& Bankuptcy law & Ordinary law \\
& Limits to cancellation of greenfield contracts (PLS 774) & Ordinary law \\
\hline \multirow{3}{*}{ Product market } & Privatization and PPP reforms (PL 9463) & Ordinary law \\
& Bolstering of regulatory agencies (PL 6621) & Ordinary law \\
\hline \multirow{2}{*}{ Trade openess } & SOE governance reforms (PL 9215, PLS 555) & Ordinary law \\
\hline
\end{tabular}

An additional element in favor of banking sector reforms is that they are relatively simple to legislate. Table 5 shows that important banking reforms can be legislated by the government alone, as they do not require congressional approval. This is also the case for several trade reforms. On the contrary, reforms of the labor market, legal system, and product market are more cumbersome from a legislative standpoint since they need to be passed with ordinary laws.

The structural reform agenda can also be influenced by fiscal space considerations. By boosting productivity and raising economic growth, structural reforms tend to have positive effects on the sustainability of fiscal accounts over the long run. Nonetheless, some reforms may involve significant short-term fiscal costs, as discussed in IMF (2017). For example, labor market reforms may require higher spending on unemployment benefits or active labor policies, as workers gradually reallocate into more productive employment opportunities. Fiscal considerations are particularly important at the current juncture in Brazil given the high and rising level of public debt.

Banking sector reforms can entail significant fiscal gains. As previously discussed, Brazil scores poorly in the structural reform index for the banking sector because of pervasive state intervention. About half of total credit to households and non-financial firms is indeed provided by public banks through earmarked programs, often at subsidized rates. According to authorities' estimates, the fiscal costs from subsidized lending amounted to 2.1 percent of GDP in 2015. Reducing public intervention in credit markets can thus entail considerable fiscal savings. 


\section{ADDITIONAL CONSIDERATIONS TO IDENTIFY REFORM PRIORITIES}

Does sequencing matter? In this paper, we have identified the key reform priorities for Brazil by looking at the impact on productivity and the extent of public support. However, this choice can be shaped by several additional factors. This section provides a brief overview of these considerations. A first issue concerns the optimal sequencing of reforms. This is related to the notion that some reforms should proceed first because they can boost public support or strengthen the economic benefits of subsequent reforms.

For example, it is generally argued that trade liberation and domestic financial reforms should precede capital account liberalization. This consideration dates to the work of McKinnon (1973), who argued that allowing for free capital flows before trade liberalization would likely exacerbate the allocative distortions due to trade barriers. Similarly, capital flows could lead to overborrowing, possibly in foreign currency, if the financial sector is not properly supervised and free of distortions. Ostry et al. (2009) find supporting empirical evidence showing that trade reforms before capital account liberalizations have a stronger positive impact on growth than the opposite sequence.

There is also evidence that trade liberalization can increase support for domestic financial reforms. Rajan and Zingales (2003) argue that competition associated with international trade weakens domestic monopolists and thus reduces their political influence against domestic financial liberalization. Hauner et al. (2013) present empirical evidence in line with this hypothesis. Trade liberalization is found to be a leading indicator of domestic financial liberalization across a broad sample of both high and low-income countries.

Furthermore, product market reforms can facilitate labor market reforms. Blanchard and Giavazzi (2003) develop a model to understand the interactions between product and labor market liberalizations. By fostering competition and lowering prices, product market reforms increase real wages. This facilitates labor market liberalization, which tends instead to reduce wages (while increasing employment). Furthermore, product reforms reduce the size of rents seized by incumbent firms. This weakens workers' incentives to unionize and oppose labor reforms to appropriate part of the rents.

Besides considerations about optimal sequencing, reform priorities can also be affected by the state of the economic cycle. Recent model-based and empirical studies find that the impact of reforms can vary significantly depending on macroeconomic conditions. More specifically, some structural reforms tend to be more beneficial when they are implemented under strong economic conditions. This is especially the case for labor market reforms, which can even become contractionary in periods of economic downturns, as for example documented in IMF (2016). In this regard, the ongoing economic recovery in Brazil provides a crucial window of opportunity to enact structural reforms.

The academic literature has also proposed to select reform priorities based on the most binding constraint for economic growth. Hausmann et al. (2008) argue that policy makers 
should first identify the most important impediment for economic development and then prioritize structural reforms to address the source of the problem. For example, they argue that Brazil's economic growth is held back primarily by limited credit supply which hinders private investment. To increase private financing, they call for fiscal consolidation to reduce crowding-out effects. They also attribute credit constraints to high intermediation margins in the financial sector. Their focus on boosting credit supply is consistent with our call for banking sector reforms that are expected to ultimately raise private investment by improving credit allocation and reducing intermediation margins.

\section{Conclusions}

The analysis suggests that banking sector reforms should be given priority. In Brazil, banking reforms to limit state intervention in credit markets have the highest impact on productivity and enjoy broad public support. Furthermore, they are relatively easy to legislate and can generate significant fiscal savings. Labor market reforms can also generate large productivity gains, but it is preferable to wait and assess the full impact of the 2017 labor reform before contemplating further measures. Besides reforming the banking sector, authorities should focus on reforms to the legal system that can also generate large productivity gains, while gathering broad public support. Reforms should strengthen the legal protection provided to individuals and their property and include measures to curb corruption.

The ongoing economic recovery in Brazil offers a crucial opportunity to enact reforms. In this paper, we have used survey data mainly to identify which structural reforms should be given priority. However, survey data provide also important information about when to enact reforms. In this regard, our analysis found that public support for structural reforms tends to increase with the pace of economic growth. The level of support for reforms in Brazil, already high relative to other Latin American countries, is thus expected to rise further as the economic recovery strengthens. Since some structural reforms tend to have more beneficial effects when the economic cycle is strong (e.g. IMF, 2016), the virtuous circle illustrated in Figure 10 may arise. Periods of sustained economic growth provide therefore a crucial opportunity to adopt structural reforms by exploiting stronger public support and maximizing the economic impact.

Figure 10. Virtuous circle between growth, public support and reforms

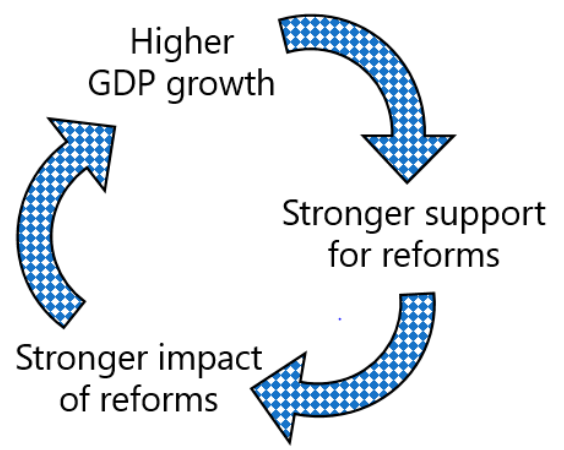




\section{REFERENCES}

Abiad, Abdul and Ashoka Mody, 2005, "Financial Reform: What Shakes it? What Shapes it?", American Economic Review, Vol. 95 (January), pp. 66-88.

Abiad, Abdul, Enrica Detragiache, and Thierry Tressel, 2010, “A New Database of Financial Reforms," Staff Papers, International Monetary Fund, Vol. 57 (February), pp. 281-302.

Baker, Andy, 2000, "Economic Policy Debates and Voter Choice in Brazil: Issues and Economy in the 1998 Presidential Elections," paper presented at the 2000 meeting of the Latin American Studies Association, Miami (March).

Blanchard, Olivier and Francesco Giavazzi, 2003, "Macroeconomic Effects of Regulation and deregulation in Goods and Labor Markets," Quarterly Journal of Economics, Vol. 118 (March), pp. 879-907.

Bouis, Romain, and Romain Duval. 2011, "Raising Potential Growth after the Crisis: A Quantitative Assessment of the Potential Gains from Various Structural Reforms in the OECD Area and Beyond," OECD Working Paper No. 835 (Organization for Economic Co-operation and Development).

Hausmann, Ricardo, Dani Rodrik, and Andres Velasco, 2008, "Growth Diagnostics," in J. Stiglitz and N. Serra, eds., The Washington Consensus Reconsidered: Towards a New Global Governance, (New York: Oxford University Press).

Hauner, David, Alessandro Prati, and Cagatay Bircan, 2013, "The Interest Group Theory of Financial Development: Evidence from Regulation," Journal of Banking and Finance, Vol. 37 (March), pp. 895-906.

International Monetary Fund, 2015, "Structural Reforms and Macroeconomic Performance: Initial Considerations for the Fund-Staff Report," IMF Policy Paper (Washington).

International Monetary Fund, 2016, "Time for a Supply-Side Boost? Macroeconomic Effects of Labor and Product Market Reforms in Advanced Economies," World Economic Outlook, Chapter 3 (Washington).

International Monetary Fund, 2017, "Labor and Product Market Reforms in Advanced Economies: Fiscal Costs, Gains and Support," Staff Discussion Note No. 17/03 (Washington).

Kingdon, John W., 2003, “Agendas, Alternatives, and Public Policies” (2nd ed.), New York: Longman.

Monroe, Alan D., 1998, "Public Opinion and Public Policy, 1980-1993." The Public Opinion Quarterly, No. 62 (January), pp. 6-28. 
McKinnon, Ronald I., 1973, "Money and Capital in Economic Development," Brookings Institution.

Organization for Economic Cooperation and Development, 2018, OECD Economic Surveys: Brazil.

Ostry, Jonathan D., Alessandro Prati and Antonio Spilimbergo, 2009, "Structural Reforms and Economic Performance in Advanced and Developing Countries," IMF Occasional Paper No. 268 (Washington: International Monetary Fund).

Page, Benjamin I. and Robert Y. Shapiro, 1992, "The Rational Public: Fifty Years of Trends in Americans' Policy Preferences," (Chicago: University of Chicago Press).

Prati, Alessandro, Massimiliano Gaetano Onorato, and Chris Papageorgiou, 2013, "Which Reforms Work and under What Institutional Environment? Evidence from a New Data Set on Structural Reforms," Review of Economics and Statistics, Vol. 95 (March), pp. 946-68.

Quinn, Dennis, 1997, "The Correlated of Change in International Financial Integration," The American Political Science Review, Vol. 91 (March), pp. 531-51.

Rajan, Raghuram, and Luigi Zingales, 2003, "The Great Reversals: The Politics of Financial Development in the Twentieth Century," Journal of Financial Economics, Vol. 69, No. 1, pp. 5-50.

Stimson, James A., Michael B. Mackuen, and Robert S. Erikson, 1995, "Dynamic Representation," The American Political Science Review, Vol. 89 (March), pp. 543-65.

Zaller, John, 1992, "The Nature and Origins of Mass Opinion," (Cambridge England; New York: Cambridge University Press). 